\title{
Anatomical study of middle cluneal nerve entrapment
}

This article was published in the following Dove Press journal:

Journal of Pain Research

13 June 2017

Number of times this article has been viewed

\author{
Tomoyuki Konno' \\ Yoichi Aota ${ }^{2}$ \\ Tomoyuki Saito' \\ Ning $\mathrm{Qu}^{3}$ \\ Shogo Hayashi ${ }^{3}$ \\ Shinichi Kawata ${ }^{3}$ \\ Masahiro Itoh ${ }^{3}$ \\ 'Department of Orthopaedic \\ Surgery, Yokohama City University, \\ ${ }^{2}$ Department of Spine and Spinal \\ Cord, Yokohama Brain and Spine \\ Center, Yokohama City, ${ }^{3}$ Department \\ of Anatomy, Tokyo Medical University, \\ Tokyo, Japan
}

Object: Entrapment of the middle cluneal nerve $(\mathrm{MCN})$ under the long posterior sacroiliac ligament (LPSL) is a possible, and underdiagnosed, cause of low-back and/or leg symptoms. To date, detailed anatomical studies of MCN entrapment are few. The purpose of this study was to ascertain, using cadavers, the relationship between the MCN and LPSL and to investigate MCN entrapment.

Methods: A total of 30 hemipelves from 20 cadaveric donors ( 15 female, 5 male) designated for education or research, were studied by gross anatomical dissection. The age range of the donors at death was 71-101 years with a mean of 88 years. Branches of the MCN were identified under or over the gluteus maximus fascia caudal to the posterior superior iliac spine (PSIS) and traced laterally as far as their finest ramification. Special attention was paid to the relationship between the MCN and LPSL. The distance from the branch of the MCN to the PSIS and to the midline and the diameter of the MCN were measured.

Results: A total of $64 \mathrm{MCN}$ branches were identified in the 30 hemipelves. Of 64 branches, 10 $(16 \%)$ penetrated the LPSL. The average cephalocaudal distance from the PSIS to where the MCN penetrated the LPSL was $28.5 \pm 11.2 \mathrm{~mm}(9.1-53.7 \mathrm{~mm})$. The distance from the midline was $36.0 \pm 6.4 \mathrm{~mm}(23.5-45.2 \mathrm{~mm})$. The diameter of the MCN branch traversing the LPSL averaged $1.6 \pm 0.5 \mathrm{~mm}(0.5-3.1 \mathrm{~mm})$. Four of the 10 branches penetrating the LPSL had obvious constriction under the ligament.

Conclusion: This is the first anatomical study illustrating MCN entrapment. It is likely that $\mathrm{MCN}$ entrapment is not a rare clinical entity.

Keywords: middle cluneal nerve, sacroiliac joint, low back pain, long posterior sacroiliac ligament, entrapment neuropathy

\section{Introduction}

Sporadic reports of a relationship between the cluneal nerve and low back pain (LBP) were published in the 1950s. In 1957, Strong and Davila attempted deafferentation of the superior cluneal nerve (SCN) and/or middle cluneal nerve (MCN) in $30 \mathrm{LBP}$ patients. ${ }^{1}$ Five of these 30 patients had referred pain in a leg in the S1 or S2 area; deafferentation of the MCN yielded favorable outcomes. Strong and Davila stated the MCNs were thin and difficult to identify during surgery, but did not describe the relationship between the MCN and long posterior sacroiliac ligament (LPSL).

Following anatomical reports by Maigne et $\mathrm{al}^{2}$ and by $\mathrm{Lu}$ et $\mathrm{al}^{3}$ that described entrapment of the most medial branch of the SCN where the nerve passes through the fascia over the iliac crest, ${ }^{4}$ successful surgical techniques were developed to open the fascial orifice for relief of this entrapment neuropathy. ${ }^{5-9}$ Trescot $^{10}$ and Kuniya et al ${ }^{11}$
Correspondence: Yoichi Aota Department of Spine and Spinal Cord Surgery, Yokohama Stoke and Brain Center, Yokohama, Kanagawa, Takigashira I-2-I, Isogo-ku, Yokohama City, Kanagawa Prefecture, Japan

$\mathrm{Tel}+8 \mathrm{I} 457532500$

Fax +8I 457532859

Email yaota@yokohama-cu.ac.jp 
stated that cluneal neuralgia is not a rare clinical entity and may be underdiagnosed and should be considered as a differential diagnosis for chronic LBP or leg pain.

No reports of MCN entrapment have been available until a recent case report that described severe LBP completely alleviated by release of the MCN. ${ }^{4}$ In this case, the MCN was entrapped where this nerve passed under the LPSL.

The MCN comprises sensory branches of the dorsal rami of S1-S3 foramina. It travels below the posterior superior iliac spine (PSIS) in an approximately horizontal course to supply the skin overlying the posteromedial area of the buttock. ${ }^{12-14}$ Controversy exists regarding a relationship between the MCN and LPSL. Tubbs et $\mathrm{al}^{14}$ reported that the MCN would be less likely to become entrapped because the MCN travels superficially to the LPSL. However, Horwitz, ${ }^{15}$ Grob et al, ${ }^{12}$ and McGrath and Zhang ${ }^{16}$ reported that the primary and secondary loops of the posterior sacral nerve plexus passed through or beneath the LPSL. These authors suggested that entrapment of the MCN under the ligament is a cause for LBP and peripartum pelvic pain. However, no studies have reported MCN entrapment under the LPSL. In view of the paucity of literature on this subject, we performed an anatomical study of the MCN around the LPSL with the objective of providing an accurate anatomical basis for clinical conditions involving entrapment of the nerve.

\section{Methods}

This anatomical study was conducted in the Department of Anatomy of Tokyo Medical University. A total of 40 usable hemipelves were obtained from 20 formalin-preserved Japanese cadavers ( 5 male and 15 female). The average age at death was 88 years and the age range was $71-101$ years. All the cadavers were routinely fixed in formalin solution. Bilateral branches of the MCN were macroscopically explored. None of the cadavers showed evidence of previous surgical procedures or traumatic lesions to the pelvis. Cadavers were placed in the prone position. Branches of the MCN were identified under or over the gluteus maximus fascia on the caudal side of the PSIS and traced laterally as far as the finest visible ramification. Special attention was paid to the relationship between the MCN and LPSL. Because lateral branches of the dorsal L5-S4 rami anastomose to form loops dorsal to the sacrum, with each branch containing nerve fibers from adjacent dorsal rami, ${ }^{15,-17}$ it was impossible to trace them individually. Therefore, the major dorsal sacral rami were dissected and traced medially to the dorsal sacral foramina to identify the level of origin. MCN branches were counted where they traversed over and under the LPSL. Distances from the branch of the MCN to the PSIS and midline and the diameter of the MCN were measured using a digimatic caliper (Mitsutoyo Corp., Kawasaki, Japan; Figure 1).

This anatomical study was approved by the Institutional Ethics Committee of our institution (Tokyo Medical University No. 2843). Cadaveric donors designated for education or research were studied.

\section{Results}

A complete exploration of the MCN failed in the initial 10 hemipelves, therefore, data from the remaining 30 hemipelves were analyzed for this study. A total of $64 \mathrm{MCN}$ branches were identified in these 30 hemipelves (Table 1). MCN branches were composed of S1-S4 dorsal rami. The distances from these anatomical landmarks are shown in Table 2 relative to origin. The distances from the PSIS to dorsal rami traversing over or under the LPSL were $\sim 20 \mathrm{~mm}$ for $\mathrm{S} 1$, $23 \mathrm{~mm}$ for S2, $34 \mathrm{~mm}$ for S3, and $41 \mathrm{~mm}$ for S4 (Table 2).

Of 30 hemipelves, 8 (specimen nos. 1, 7, 9, 11, 21, 24, 26, and 28) had one (Figure 2) and 1 (specimen no. 5) had two MCN branches traversing under the LPSL. The 10 penetrating $\mathrm{MCN}$ branches were lateral branches of the dorsal sacral rami, most commonly from $\mathrm{S} 2$ and more rarely from S1, S3, or S4 foramina. The average cephalocaudal distance from the PSIS of LPSL penetration was $23.2 \mathrm{~mm}$ $(12.5-42.1 \mathrm{~mm})$. The average distance from the midline was

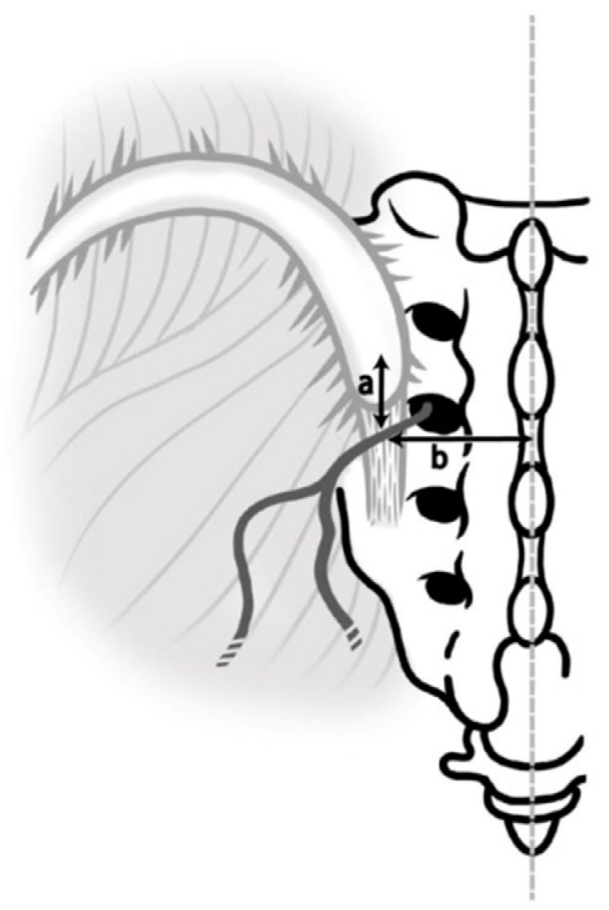

Figure I Schematic illustration of measurements of linear distances from the posterior superior iliac spine (distance a) and the midline (distance b) to a branch of the MCN traversing over or under the LPSL.

Abbreviations: LPSL, long posterior sacroiliac ligament; MCN, middle cluneal nerve. 
Table I Spinal levels of sacral nerve roots originating MCN branches

\begin{tabular}{|c|c|c|c|c|c|c|c|c|c|c|c|c|c|c|c|c|c|c|c|c|c|c|c|c|c|c|c|c|c|c|}
\hline Specimen no. & & 2 & 3 & 4 & 5 & 6 & 7 & 8 & 9 & 10 & 11 & 12 & 13 & 14 & 15 & 16 & 17 & 18 & 19 & 20 & 21 & 22 & 23 & 24 & 25 & 26 & 27 & 28 & 29 & 30 \\
\hline SI & & & 0 & $\mathrm{O}$ & $\underline{0}$ & $\mathrm{O}$ & & & & $\mathrm{O}$ & & & & 0 & & & 0 & 0 & & & 0 & & 0 & $\underline{0}$ & 0 & & $\mathrm{O}$ & & & $O \triangle$ \\
\hline S2 & 으 & 0 & & $\square$ & & & 1 & 0 & O & & 0 & 0 & 0 & $\square$ & O & O & $O \triangle$ & & 0 & $O \square$ & $\square$ & $O \square$ & $\square$ & $\bar{\Delta}$ & $\square$ & $\underline{0}$ & & $\underline{\underline{0}}$ & O & $\triangle$ \\
\hline S3 & $\square$ & $\square$ & & & $\square$ & & & & 므 & $\square$ & & $\triangle$ & 0 & & & $\square$ & $\Delta \square$ & & & & & & & & & $\bar{\Delta}$ & $\triangle$ & $\overline{\underline{\rho}} \Delta$ & $\Delta$ & $\square$ \\
\hline S4 & & & & & & & $\square$ & $\square$ & & & $\square$ & $\square$ & & & & $\square$ & $\square$ & & $\square$ & & & & & $\square$ & & $\square$ & $\square$ & $\bar{\square}$ & $\square$ & \\
\hline
\end{tabular}

Notes: $\bigcirc$, Cephalad branch; $\triangle$, Middle branch; $\square$, Caudal branch. Under bar $\left(\_\right.$) represents branch passing under LPSL, Black marks represent a branch with macroscopic indentation by the LPSL.

Abbreviations: MCN, middle cluneal nerve; LPSL, long posterior sacroiliac ligament.

Table 2 Measurements of $\mathrm{MCN}$ branches relative to origin

\begin{tabular}{llll}
\hline $\begin{array}{l}\text { Nerve } \\
\text { roots }\end{array}$ & $\begin{array}{l}\text { Distance } \\
\text { from midline } \\
(\mathbf{m e a n} \pm S D)\end{array}$ & $\begin{array}{l}\text { Distance from } \\
\text { PSIS (mean } \pm S D) \\
(\mathbf{m m})\end{array}$ & $\begin{array}{l}\text { Diameter of } \\
\text { MCN (mean } \pm S D) \\
(\mathbf{m m})\end{array}$ \\
\hline SI $(n=15)$ & $33.1 \pm 7.2$ & $20.7 \pm 5.0$ & $1.7 \pm 0.6$ \\
S2 $(n=27)$ & $37.0 \pm 6.1$ & $23.3 \pm 7.9$ & $1.7 \pm 0.6$ \\
S3 $(n=17)$ & $37.9 \pm 4.9$ & $33.9 \pm 9.3$ & $1.4 \pm 0.3$ \\
S4 $(n=12)$ & $34.6 \pm 6.7$ & $41.0 \pm 10.4$ & $1.3 \pm 0.3$ \\
\hline
\end{tabular}

Abbreviations: MCN, middle cluneal nerve; PSIS, posterior superior iliac spine; $\mathrm{SD}$, standard deviation.

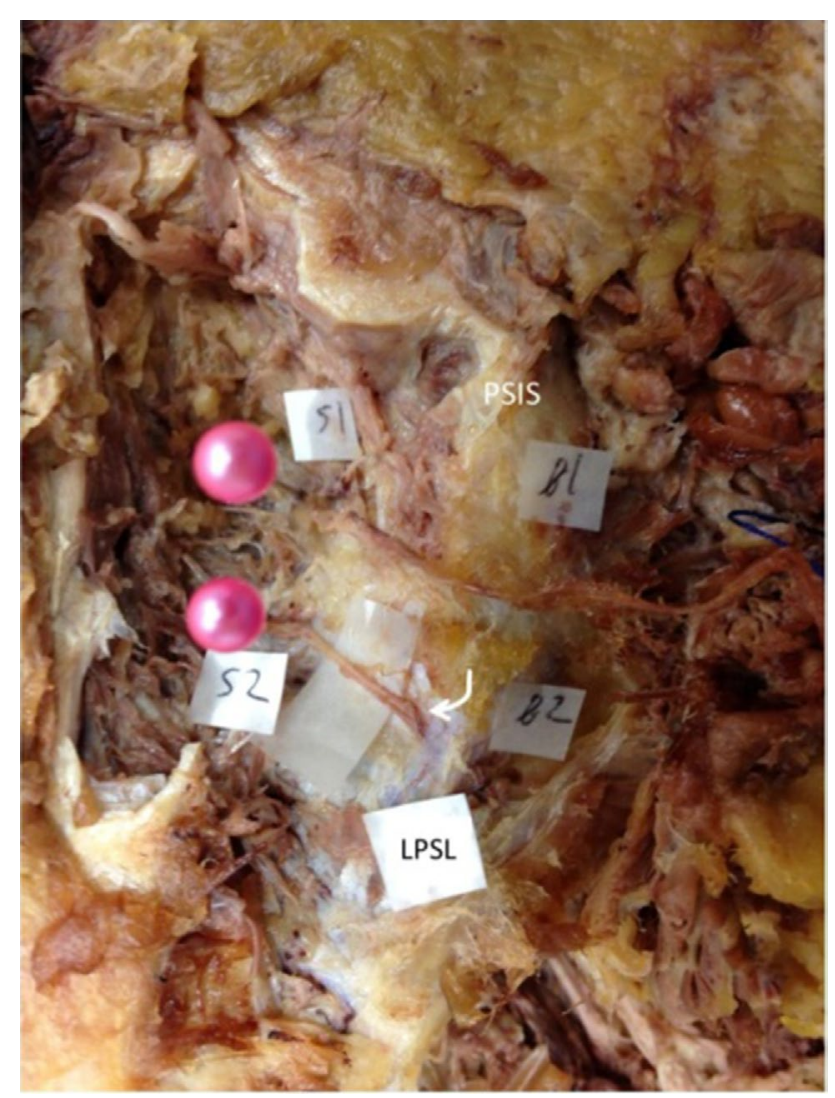

Figure 2 Photograph showing MCN branches traversing over and under the LPSL on the left side in a cadaveric specimen obtained from an 88-year-old woman (specimen no. 2I).

Notes: The cephalad branch (bl) originates from SI foramen and traverses over the LPSL. The caudal branch (b2) originates from S2 foramen and enters into the LPSL (curved arrow). SI and S2 foramina are indicated by two pink needles.

Abbreviations: MCN, middle cluneal nerve; PSIS, posterior superior iliac spine; LPSL, long posterior sacroiliac ligament.

$34.5 \mathrm{~mm}(26.9-43.6 \mathrm{~mm})$. The MCN branch was quite thin, with an average width of $1.6 \mathrm{~mm}(1.0-2.2 \mathrm{~mm})$ measured at the point where it traversed the LPSL. Four of the $10 \mathrm{MCN}$ branches passing under the LPSL had marked narrowing from constriction under the LPSL (Figures 3 and 4).

Some of the penetrating MCN branches extended a thin nerve fiber that disappeared into the sacroiliac joint (SIJ). Anastomosis between the MCN and SCN was sometimes found in subcutaneous tissues of the buttock. We also found some communicating branches from the $\mathrm{MCN}$ to the superior gluteal nerve (SGN).

\section{Discussion}

The LPSL is a significant posterior SIJ ligamentous structure that resists shearing of the SIJ. ${ }^{17,18}$ SIJ pain has been a controversial and ill-defined subject. SIJ disorders have an imprecise etiology and are thought to cause $15 \%-30 \%$ of LBP and are often associated with buttock to lower extremity symptoms. ${ }^{19}$ There are no medical history, physical examination, or radiological findings consistently capable of identifying SIJ pain. ${ }^{20}$ The current gold standard for diagnosis of SIJ pain is fluoroscopically guided SIJ blocks. ${ }^{19}$ Radiofrequency ablation or blocking of the lateral branches of the dorsal sacral rami that supply the SIJ is a treatment option gaining considerable attention. ${ }^{21,22}$

Several researchers consider the LPSL to be a major pain generator of SIJ pain. ${ }^{16,18,23-25}$ Fortin and Falco $^{20}$ stated that SIJ patients could localize their pain with one finger and the area pointed to was within $1 \mathrm{~cm}$ inferomedial to
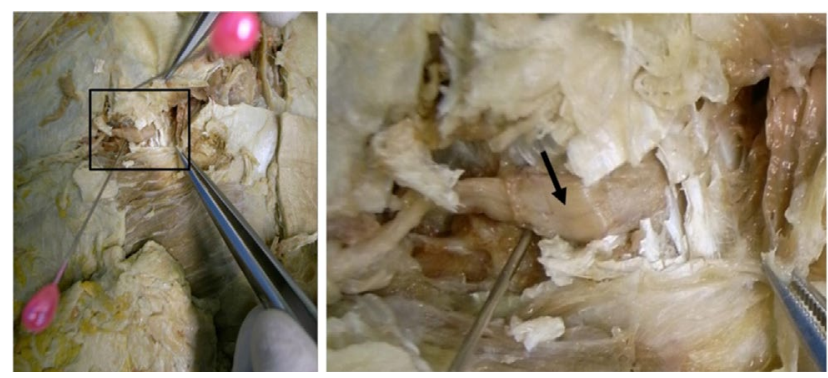

Figure 3 Photographs (overview of pelvis, left and close view, right) showing entrapment of the MCN under the LPSL obtained from an 85-year-old woman (specimen no. 7).

Notes: A part of the LPSL is cut and reflected medially by forceps. The superior branch of the MCN is constricted and obviously flattened in the LPSL (arrow). The lower needle indicates the lateral margin of the LPSL. The upper needle indicates the posterior superior iliac spine.

Abbreviations: MCN, middle cluneal nerve; LPSL, long posterior sacroiliac ligament. 


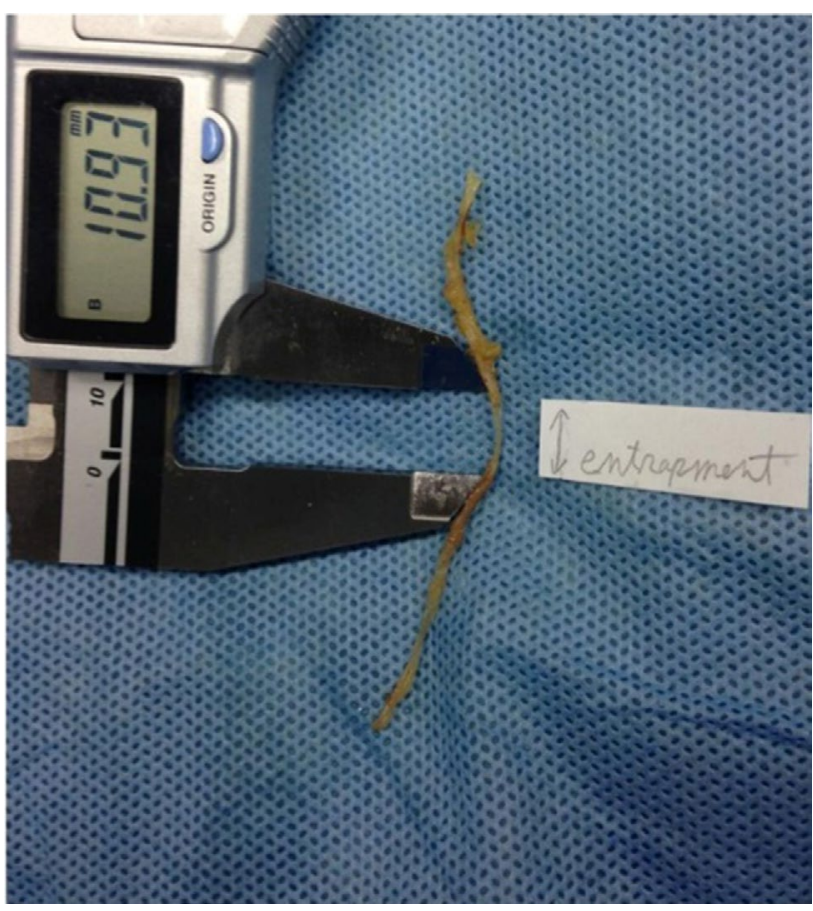

Figure $4 \mathrm{~A}$ narrowed portion of the $\mathrm{MCN}$ obtained from an $8 \mathrm{I}$-year-old woman (specimen no. I). Approximately $10 \mathrm{~mm}$ of the $\mathrm{MCN}$ is narrowed, reflecting the width of the LPSL.

Abbreviations: MCN, middle cluneal nerve; LPSL, long posterior sacroiliac ligament.

the PSIS. Murakami et al ${ }^{24}$ observed positive effects from a periarticular SIJ block in 18 of 25 patients who located the primary site of their pain to within $2 \mathrm{~cm}$ of the PSIS. Murakami et a ${ }^{25}$ compared the effect of blocking injections into the intraarticular space and around the LPSL in patients fulfilling definite criteria for SIJ pain. Blocking injections around the LPSL were effective in all 25 patients, whereas intraarticular blocking injections were effective in only 9 out of 25 patients (36\%). In addition, all 16 patients without pain relief after an intraarticular blocking injection reported almost complete pain relief after a blocking injection around the LPSL. In a recent anatomical report by Cox and Fortin, ${ }^{21}$ which attempted to clarify innervation of the SIJ by the lateral branches, the authors stated that the most lateral portion of the lateral branch of S1 was traced after it passed through a fibro-osseous tunnel in the LPSL. ${ }^{21}$ In our study, 10 of $64 \mathrm{MCN}$ branches passed under the LPSL. It is likely that blocks around the LPSL may infiltrate around the dorsal sacral rami passing over or under the LPSL.

This paper is the first anatomical report illustrating obvious entrapment of the MCN under the LPSL. The fact that entrapment under the LPSL was identified in 4 of 30 cadavers (13\%) indicates MCN entrapment is not a rare clinical entity. We agree with the concept that the LPSL is a potential pain generator. Our findings suggest that pain may be induced not only by mechanical stress in the ligament but also by nerve compression under the ligament.

Large epidemiological studies show that back pain in $16 \%-55 \%$ of patients has a neuropathic pain component. ${ }^{26-32}$ The wide variation in the prevalence is perhaps due to differences in terms of the definition of neuropathic pain and in methodology between studies. When compared with LBP without a neuropathic component, neuropathic LBP is associated with severity of comorbidities, ${ }^{26,29,33}$ reduced quality of life, ${ }^{26}$ and higher health care costs. ${ }^{33-35}$ Neuropathic pain is thought to be produced by lesions of nociceptive sprouts within the degenerated disc, mechanical compression of the nerve root, or action of inflammatory mediators originating from the degenerated disc. ${ }^{28} \mathrm{SCN}$ and/or MCN entrapment must be considered as a cause of neuropathic LBP.

\section{Disclosure}

The authors report no conflicts of interest in this work.

\section{References}

1. Strong EK, Davila JC. The cluneal nerve syndrome; a distinct type of low back pain. Ind Med Surg. 1957;26(9):417-429.

2. Maigne JY, Lazareth JP, Guerin Surville H, Maigne R. The lateral cutaneous branches of the dorsal rami of the thoraco-lumbar junction. An anatomical study on 37 dissections. Surg Radiol Anat. 1989;11:289-293.

3. Lu J, Ebraheim NA, Huntoon M, Heck BE, Yeasting RA. Anatomic considerations of superior cluneal nerve at posterior iliac crest region. Clin Orthop Relat Res. 1998;(347):224-228.

4. Aota Y. Entrapment of middle cluneal nerves as an unknown cause of low back pain. World J Orthop. 2016;7(3):167-170.

5. Berthelot JM, Delecrin J, Maugars Y, Caillon F, Prost A. A potentially underrecognized and treatable cause of chronic back pain: entrapment neuropathy of the cluneal nerves. J Rheumatol. 1996;23(12):2179-2181.

6. Kim K, Isu T, Chiba Y, et al. The usefulness of ICG video angiography in the surgical treatment of superior cluneal nerve entrapment neuropathy: technical note. J Neurosurg Spine. 2013;19(5):624-628.

7. Maigne JY, Doursounian L. Entrapment neuropathy of the medial superior cluneal nerve. Nineteen cases surgically treated, with a minimum of 2 years' follow-up. Spine (Phila Pa 1976). 1997;22(10):1156-1159.

8. Morimoto D, Isu T, Kim K, et al. Surgical treatment of superior cluneal nerve entrapment neuropathy. J Neurosurg Spine. 2013;19(1):71-75.

9. Speed S, Sims K, Weinrauch P. Entrapment of the medial branch of the superior cluneal nerve a previously unrecognized cause of lower back pain in cricket fast bowlers. J Med Cases. 2001;2:101-103.

10. Trescot AM. Cryoanalgesia in interventional pain management. Pain Physician. 2003;6(3):345-360.

11. Kuniya H, Aota Y, Kawai T, Kaneko K, Konno T, Saito T. Prospective study of superior cluneal nerve disorder as a potential cause of low back pain and leg symptoms. J Orthop Surg Res. 2014;9:139.

12. Grob KR, Neuhuber WL, Kissling RO. Die innervation des sacroiliaclenkes beim menschen. [Innervation of the sacroiliac joint of the human]. Z Rheumatol. 1995;54(2):117-122. German.

13. Sittitavornwong S, Falconer DS, Shah R, Brown N, Tubbs RS. Anatomic considerations for posterior iliac crest bone procurement. JOral Maxillofac Surg. 2013;71(10):1777-1788.

14. Tubbs RS, Levin MR, Loukas M, Potts EA, Cohen-Gadol AA. Anatomy and landmarks for the superior and middle cluneal nerves: application to posterior iliac crest harvest and entrapment syndromes. J Neurosurg Spine. 2010;13(3):356-359. 
15. Horwitz TM. The anatomy of (A) the lumbosacral nerve plexus - its relation to variations of vertebral segmentation, and (B) the posterior sacral nerve plexus. Anat Rec. 1939;74(1):91-107.

16. McGrath MC, Zhang M. Lateral branches of dorsal sacral nerve plexus and the long posterior sacroiliac ligament. Surg Radiol Anat. 2005; 27(4):327-330.

17. Standring S, editor. Gray's Anatomy. The Anatomical Basis of Medicine and Surgery, 38th ed. Edinburgh: Churchill Livingstone; 2008.

18. Vleeming A, Pool-Goudzwaard AL, Hammudoghlu D, Stoeckart R, Snijders CJ, Mens JM. The function of the long dorsal sacroiliac ligament: its implication for understanding low back pain. Spine (Phila Pa 1976). 1996;21(5):556-562.

19. Vanelderen P, Szadek K, Cohen SP, et al. 13. Sacroiliac joint pain. Pain Pract. 2010;10(5):470-478.

20. Fortin JD, Falco FJ. The Fortin finger test: an indicator of sacroiliac pain. Am J Orthop (Belle Mead NJ). 1997;26(7):477-480.

21. Cox RC, Fortin JD. The anatomy of the lateral branches of the sacral dorsal rami: implications for radiofrequency ablation. Pain Physician. 2014;17(5):459-464.

22. Fortin JD, Washington WJ, Falco FJ. Three pathways between the sacroiliac joint and neural structures. AJNR Am J Neuroradiol. 1999; 20(8):1429-1434.

23. Cusi M, Van der Wall H, Saunders J, Wong L, Pearson M, Fogelman I. Sacroiliac steroid injections do not predict ablation relief-not a surprise. Pain Med. 2013;14(1):163-164.

24. Murakami E, Aizawa T, Noguchi K, Kanno H, Okuno H, Uozumi H. Diagram specific to sacroiliac joint pain site indicated by one-finger test. J Orthop Sci. 2008;13(6):492-497.

25. Murakami E, Tanaka Y, Aizawa T, Ishizuka M, Kokubun S. Effect of periarticular and intraarticular lidocaine injections for sacroiliac joint pain: prospective comparative study. J Orthop Sci. 2007;12(3): 274-280.
26. Beith ID, Kemp A, Kenyon J, Prout M, Chestnut TJ. Identifying neuropathic back and leg pain: a cross-sectional study. Pain. 2011;152(7): 1511-1516.

27. Fishbain DA, Cole B, Lewis JE, Gao J. What is the evidence that neuropathic pain is present in chronic low back pain and soft tissue syndromes? An evidence-based structured review. Pain Med. 2014;15(1): 4-15.

28. Freynhagen R, Baron R. The evaluation of neuropathic components in low back pain. Curr Pain Headache Rep. 2099;13(3):185-190.

29. Freynhagen R, Baron R, Gockel U, Tolle TR. painDETECT: a new screening questionnaire to identify neuropathic components in patients with back pain. Curr Med Res Opin. 2006;22(10):1911-1920.

30. Freynhagen R, Baron R, Tolle T, et al. Screening of neuropathic pain components in patients with chronic back pain associated with nerve root compression: a prospective observational pilot study (MIPORT). Curr Med Res Opin. 2006;22(3):529-537.

31. Hassan AE, Saleh HA, Baroudy YM, et al. Prevalence of neuropathic pain among patients suffering from chronic low back pain in Saudi Arabia. Saudi Med J. 2004;25(12):1986-1990.

32. Kaki AM, El-Yaski AZ, Youseif E. Identifying neuropathic pain among patients with chronic low-back pain: use of the Leeds Assessment of Neuropathic Symptoms and Signs pain scale. Reg Anesth Pain Med. 2005; 30(5):422-428.

33. Mehra M, Hill K, Nicholl D, Schadrack J. The burden of chronic low back pain with and without a neuropathic component: a healthcare resource use and cost analysis. J Med Econ. 2012;15(2):245-252.

34. Berger A, Dukes EM, Oster G. Clinical characteristics and economic costs of patients with painful neuropathic disorders. J Pain. 2004; 5(3):143-149.

35. Schmidt CO, Schweikert B, Wenig CM, et al. Modelling the prevalence and cost of back pain with neuropathic components in the general population. Eur J Pain. 2009;13(10):1030-1035.

\section{Journal of Pain Research}

\section{Publish your work in this journal}

The Journal of Pain Research is an international, peer reviewed, open access, online journal that welcomes laboratory and clinical findings in the fields of pain research and the prevention and management of pain. Original research, reviews, symposium reports, hypothesis formation and commentaries are all considered for publication

\section{Dovepress}

The manuscript management system is completely online and includes a very quick and fair peer-review system, which is all easy to use. Visit http://www.dovepress.com/testimonials.php to read real quotes from published authors. 